\title{
THE EFFECTIVITY OF ADDITION CHEST MOBILIZATION OR PURSED LIP BREATHING IN CONVENTIONAL THERAPY IN COPD PATIENTS
}

\author{
Fidyatul Nazhira ${ }^{\text {* }}$, I Made Muliarta ${ }^{2}$, Wahyuddin $^{3}$, Putu Astawa ${ }^{4}$, Anak Agung Sagung Sawitri ${ }^{5}$, \\ Susy Purnawati ${ }^{2}$ \\ ${ }^{1}$ Sport Physiology Magister Program, Faculty of Medicine, Universitas Udayana, 80234, Denpasar, Indonesia \\ 2 Physiology Department, Faculty of Medicine, Universitas Udayana, 80234, Denpasar, Indonesia \\ ${ }^{3}$ Faculty of Physiotherapy Universitas Esa Unggul, 11510, Jakarta, Indonesia \\ ${ }^{4}$ Orthopedics and Traumatology Department, Faculty of Medicine, Universitas Udayana, 80234, Denpasar, Indonesia \\ ${ }^{5}$ Community Medicine Department, Faculty of Medicine, Universitas Udayana, 80234, Denpasar, Indonesia \\ fidyatulnazhira@gmail.com
}

\begin{abstract}
Background: Chronic obstructive pulmonary disease (COPD) is an accumulation of pulmonary pathologies that causes limited airflow, then breathlessness. Chest mobilization and pursed lip breathing (PLB) are physiotherapy management aimed at reducing pulmonary hyperinflation, increasing FEV1 and improve breathlessness. The purpose of this study was to determine differences effectiveness of addition chest mobilization or PLB in conventional therapy to increase FEV1 and improve breathlessness in COPD patients at Lung Hospital dr. Ario Wirawan Salatiga. Research methods: This study is true experiment with pretest and posttest control group design. The subjects numbered 30 people then divided into 3 groups. All groups were given treatment 3 times a week for 6 weeks. Group I received additional chest mobilization, group II received additional PLB and group III received only conventional hospital intervention. FEV1 was measured using spirometry, breathlessness was measured using modified Borg scale. Results: Based on Wilcoxon sign rank test, there was an increase in FEV1 and improve breathlessness with $p>0.05$ in group I and group II. In group III there was an increase in FEV1 but no improve breathlessness. Different test results on increasing FEV1 between groups based on the Kruskal-Wallis t-test obtained $p>0.05$. Different test for improve breathlessness between groups I and II using Mann Whitney U-test $p$-value $>0.05$. Conclusion: The addition of chest mobilization or PLB to conventional therapy is as good as conventional hospital intervention only in increasing FEV1 and improve breathlessness in COPD patients at Lung Hospital dr. Ario Wirawan Salatiga.

Keyword: COPD; Breathlessness; FEV 1; Chest Mobilization; Pursed Lip Breathing
\end{abstract}

\section{INTRODUCTION}

Chronic obstructive pulmonary disease (COPD) is a constellation of pulmonary physiological disorders, the main of which is the progressive nonreversible or partially reversible airflow obstruction. This disease involves in pathological changes in the respiratory system causing shortness of breath and coughing. The decrease in lung capacity and shortness of breath that occurs in COPD has an impact on decreasing activity tolerance. Airflow obstruction causes muscle dysfunction. The average prevalence of muscle weakness is around $20-40 \%$ depending on the severity of the disease. However, the decrease in limb muscle endurance and muscle fatigue is about $30-80 \%$. Impairment of limb muscle function in COPD is heterogeneous with limb strength and endurance ${ }^{1}$.

COPD is estimated by WHO to be the 3 biggest cause of death in 2030. In the United States, data for 2007 show that the prevalence of COPD is $10.1 \%$, for men it is $11.8 \%$ and for women it is $8.5 \%{ }^{1}$. The highest prevalence of COPD in Indonesia is in NTB (10\%), while in Java, the prevalence of COPD sufferers is West Java $4.0 \%$, East Java $3.6 \%$ and Central Java $3.4 \%{ }^{2}$.

Obstructed expiratory airflow is caused by obstructions so that air is trapped and hyperinflation occurs. Hyperinflation increases the tension in the respiratory muscles because it causes the muscles to work in a limited range of motion (ROM) so it happened fatigue and increased tightness ${ }^{3}$. Limitations of thoracic expansion causing loss of mobility or movement in the costochondral, costotransverse and costovertebral joints. Failure to expand the lungs maximally causes an increase in elasticity of the lung tissue and chest wall and limits the fulfillment of air that enters the lungs ${ }^{4}$.

Physiotherapy management in COPD is a deep breathing exercise, endurance and strengthening exercises for primary and secondary respiratory muscles, and mobilization of the thoracic cage. Increase of 
mobility in the thoracic cage and increase Forced Expiratory Volume in 1 second (FEV1) / Forced Volume Capacity (FVC) ratio after rib cage mobilization for 3 weeks, 5 days a week. Chest mobilization also has a significant immediate effect on improving lung expansion ${ }^{5}$. Pursed lip breathing (PLB) affects the breathing pattern by extending expiration, reducing the functional recidual capacity (FRC) and increasing ventilation efficiency ${ }^{6}$. The physiological changes induced by PLB causes increase in intrabronchial pressure during expiration and, thus, an increase in bronchial diameter, thereby increasing inspiratory and expiratory flow. Positive intrabronchial pressure prevents the collapse of the bronchi during expiration and, therefore, can increase the inspiration capacity (IC) and vital capacity ${ }^{7}$.

\section{METHODS}

a. Methodology

Study Design

The research method is true experimental, and the research design used is the Pre and Post Test Groups Design

\section{Subject recruitment}

The ethical number of this study is 151 / I / HREC / 2020 on 4 February 2020. Population was all patients diagnosed with COPD at Pulmonary Hospital dr. Ario Wirawan. Research time in February - March 2020. The inclusion criteria were COPD patients based on doctor's examination and physiotherapy, aged between 45-70 years, cooperative and willing to join the research program, COPD grade 1-3 based on GOLD. Exclusion criteria were patients who had received other interventions, vital conditions were unstable, musculoskeletal abnormalities in the upper extremities such as fractures of the upper extremities (ribs, shoulders and necks), patients with ischemic heart disease, rheumatic heart disease, bone cancer metastases, tuberculosis spondylitis, severe pain, and herniation.

\section{Sampling technique}

The research sample was based on inclusion and exclusion criteria. Based on the Pocock formula, the sample size is 30 people. Then they divided into 3 groups using random sampling technique. Group I was given chest mobilization and conventional hospital intervention, group II was given PLB conventional hospital intervention, and group III was given only conventional hospital intervention in the form of SOP from Pulmonary Hospital dr. Ario Wirawan Salatiga

b. Material and procedure

i. Group 1 was given chest mobilization and conventional hospital intervention which chest mobilization was carried out in a sitting and lying position. Based on Parmar and Bhise (2015. Each movement is done 3 times.

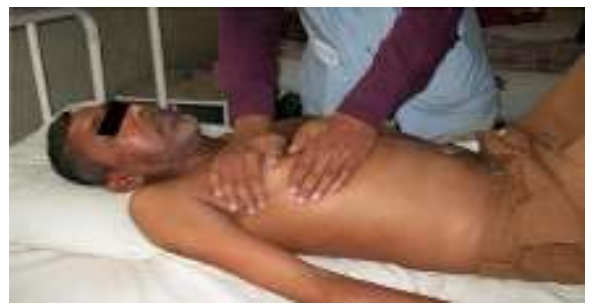

Figure 1. Rib Rotation

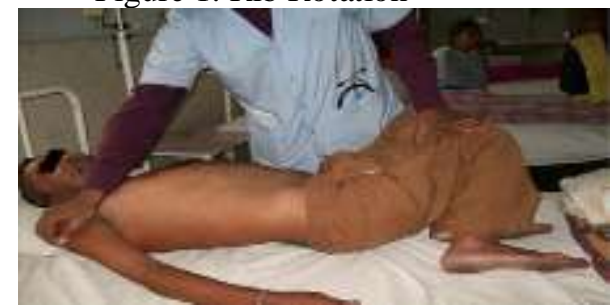

Figure 2. Chest Wall Rotation

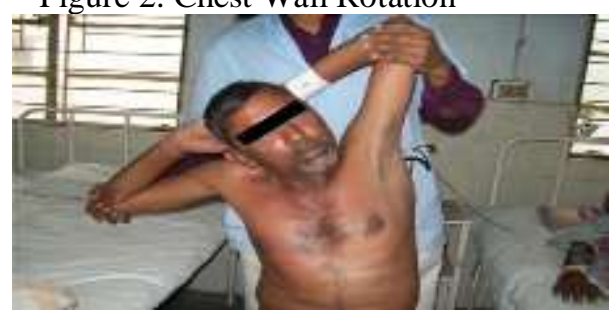

Figure 3. Lateral Flexion of Chest Wall 


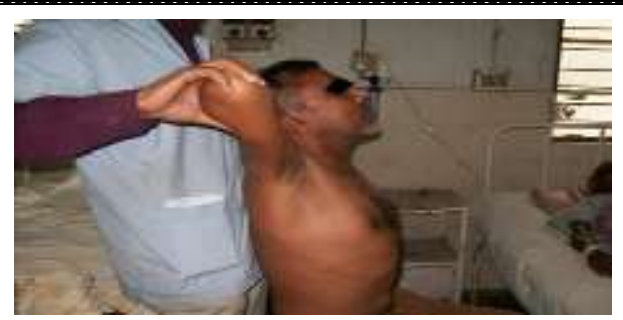

Figure 4. Chest Wall Extension

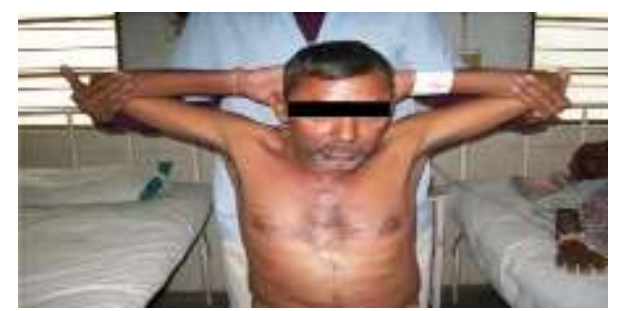

Figure 5. Pectoralis Major Muscle Stretching

ii. Group 2 was given PLB and conventional hospital intervention. Respondents were trained to breathe by relaxing neck and shoulder muscles and inhaling air through the nose and counting to a count of 2 and closing the mouth. In exhalation, should slowly exhale air by extending the exhalation time by counting 1 to 5. Additional intervention was carried out 3 times a week for 6 weeks.

iii. Group 3 was given conventional intervention is SOP from Pulmonary Hospital dr. Ario Wirawan Salatiga in the form of mental health and physiotherapy services.

c. Assessment

The evaluations measured were \%FEV1 against predictions using Spirolab MIR brand of spirometry, and shortness of breath using a modified Borg scale questionnaire.

d. Data Analysis

i. The normality test uses the Shapiro-Wilk test.

ii. Homogeneity test using Levene's test

iii. The difference test before and after treatment for groups I, II, and III used the Wilcoxon sign rank test because all data were not normally distributed so that they were comparable with different tests.

iv. The increase of FEV 1 post intervention differential test between group I, II and group III used the Kruskal-Wallis t-test

v. The improvement of brearthlessness post intervention differential test between group I, II and group III used the Mann Whitnet U-test

vi. Data analysis used IBM SPSS Statistics for Windows, Version 20.0. Armonk, NY: IBM Corp.

\section{RESULTS}

\section{Characteristic of Subjects}

Based on Table 1, the most ages are in the age range 56-65 as many as 13 people, with a mean value of $61 \pm$ 5.5 years in Group I, $59.7 \pm 8.68$ years in Group II and $59.8 \pm 5.99$ years in Group III. BMI characteristics data showed that most results were in the normal category. Most COPD grade was in grade 3 and $76 \%$ of the respondents were smokers. Based on the results of Lavene's test, the data distribution was stated to be homogeneous.

\section{Data Normality Test}

All data were normally distributed to be compatible with different tests after intervention.

\section{FEV1 Difference Test and Modified Borg Scale Before and After Intervention in Each Group}

Based on Table 2, group I and group II showed a difference between FEV 1 and modified Borg scale before and after the addition of chest mobilization or PLB interventions. Group III showed a difference from FEV 1 but there was no difference from the modified Borg scale before and after conventional intervention in COPD patients. 
Difference Test After Intervention in Chest Mobilization, Pursed Lip Breathing and Conventional Groups

Table 3 and Table 4 show that from the p-value the mean FEV 1 result, there was no difference between the three groups after the intervention. The result of the modified Borg scale mean calculation also means that there is no difference between the three groups after the intervention. The same result also occurs in the difference between FEV 1 and modified Borg scale.

Table 1. Respondent Data Distribution and Homogeneity Test

\begin{tabular}{|c|c|c|c|c|c|c|c|}
\hline \multirow{2}{*}{ Characteristics } & \multicolumn{2}{|c|}{ Group I } & \multicolumn{2}{|c|}{ Group II } & \multicolumn{2}{|c|}{ Group III } & \multirow[t]{2}{*}{ p -value } \\
\hline & (f) & $(\%)$ & (f) & $(\%)$ & (f) & $(\%)$ & \\
\hline \multicolumn{8}{|l|}{ Age } \\
\hline 46-55 Years & 3 & 30 & 3 & 30 & 1 & 10 & \multirow{3}{*}{$0,125^{1}$} \\
\hline 56-65 Years & 4 & 40 & 3 & 30 & 8 & 80 & \\
\hline$>65$ Years & 3 & 30 & 4 & 40 & 1 & 10 & \\
\hline \multicolumn{8}{|l|}{ Gender } \\
\hline Man & 10 & 100 & 10 & 100 & 10 & 100 & \\
\hline \multicolumn{8}{|l|}{ BMI $\left(\mathrm{kg} / \mathrm{m}^{2}\right)$} \\
\hline Underweight & 0 & 00 & 2 & 20 & 2 & 20 & \multirow{3}{*}{$0,936^{1}$} \\
\hline Normal & 8 & 80 & 6 & 60 & 7 & 70 & \\
\hline Overweight & 2 & 20 & 2 & 20 & 1 & 10 & \\
\hline \multicolumn{8}{|l|}{ Grade COPD } \\
\hline Grade 1 & 1 & 10 & 0 & 0 & 2 & 20 & \multirow{3}{*}{$0,100^{1}$} \\
\hline Grade 2 & 3 & 30 & 7 & 70 & 2 & 20 & \\
\hline Grade 3 & 6 & 60 & 3 & 30 & 6 & 60 & \\
\hline \multicolumn{8}{|l|}{ Smoking Status } \\
\hline Smoking & 8 & 80 & 7 & 70 & 8 & 80 & \multirow[t]{2}{*}{$0,553^{1}$} \\
\hline Not Smoking & 2 & 20 & 3 & 30 & 2 & 20 & \\
\hline
\end{tabular}

Table 2. Different Test Results FEV1 and Modified Borg Scale Before and After Intergroup Intervention Based on Wilcoxon Sign Rank Test

\begin{tabular}{lllllll}
\hline & \multicolumn{2}{c}{ Group I } & \multicolumn{2}{c}{ Group II } & \multicolumn{2}{c}{ Group III } \\
\cline { 2 - 7 } & FEV 1 (\%) & modified Borg scale & FEV 1 (\%) & modified Borg scale & FEV 1 (\%) & modified Borg scale \\
\hline Before & $49,2 \pm 20,24$ & $4,2 \pm 1,68$ & $54,7 \pm 14,49$ & $4 \pm 1,33$ & $50,9 \pm 23,01$ & $3,3 \pm 0,95$ \\
\hline After & $56,5 \pm 21,37$ & $3,2 \pm 1,31$ & $62 \pm 19,78$ & $2,8 \pm 1,47$ & $53,7 \pm 24,1$ & $2,8 \pm 0,79$ \\
\hline P value & 0,008 & $0,026^{2}$ & 0,010 & 0,016 & 0,018 & 0,059 \\
\hline
\end{tabular}

Table 3. Different Test Results FEV1 (\%) and Modified Borg Scale After Intervention Based on Kruskal-Wallis Test

\begin{tabular}{lcc} 
& $\begin{array}{c}\text { FEV 1 } \\
\text { (Mean } \pm \text { SD) }\end{array}$ & $\begin{array}{c}\text { Selisih FEV 1 } \\
(\text { Mean } \pm \text { SD) }\end{array}$ \\
\hline Group 1 & $56,5 \pm 21,37 \%$ & $7,3 \pm 9,40 \%$ \\
\hline Group 2 & $62 \pm 19,78 \%$ & $7,3 \pm 8,35 \%$ \\
\hline Group 3 & $53,7 \pm 24,1 \%$ & $2,8 \pm 3,73 \%$ \\
\hline P Value & 0,597 & 0,159 \\
\hline
\end{tabular}

Tablel4. Result of different test of modified borg scale after intervention Group 1 and Group 2 Based on Mann Whitney U-Test

$$
\begin{gathered}
\text { Difference Modified Borg Scale } \\
\text { (Mean } \pm \text { SB) }
\end{gathered}
$$

\begin{tabular}{lcc}
\hline Group 1 & $1 \pm 1,05$ & $(\mathbf{M e a n} \pm \mathbf{S B})$ \\
\hline Group 2 & $1,2 \pm 1,03$ & $3,2 \pm 1,31$ \\
\hline P Value & 0,684 & $2,8 \pm 1,47$ \\
\hline
\end{tabular}

\section{DISCUSSION}

Age is a factor that affects a person's lung function. In the aging process, there will be a decrease in various structures and functions of cells, tissues and organ systems including the lung organs. Vital capacity (VC) decreases by 10-20 mL per year in normal aging and about $30 \mathrm{~mL}$ in COPD patients. Residual volume 
increases in aging lungs and COPD. In addition, elastic elasticity, mucociliary clearance, immunity and vascular reserve are decreased in the elderly and more in COPD patients. FEV1 and FVC increase until the age of 20 in women and 27 in men, then decreases in old age. However, the exact changes in parents are unclear. The decrease can accelerate beyond the age of 60 and remain stable throughout the 60-90 year age range ${ }^{8}$. In addition, BMI is also an important indicator for evaluating the condition of COPD patients and long-term management of chronic disease. A higher BMI has more nutritional intake or is in a good nutritional status resulting in lower levels of inflammation and fewer exacerbations compared with underweight patients.

Chest mobilization helps in the flexibility of the thoracic wall, respiratory muscle function, and ventilation pumps, thereby relieving symptoms of shortness of breath and use of the auxiliary muscles ${ }^{9}$. In addition, COPD patients showed an increase in the AP diameter of the thoracic cage compared to normal people. BMI also has an effect in increasing the AP diameter. Hyperinflation and fatigue of the respiratory muscles produce hypertonicity in the respiratory muscles and hypomobility of the spinal, rib, and sternal joints that arrange the chest wall ${ }^{10,11}$. Chest mobilization can increase FEV, FVC and peak expiratory flow significantly. This occurs because there is an increase in the movement of the shoulder gridle, trunk, and chest wall, increasing breathing so that the tightness will be reduced. Chest mobilization can increase chest wall expansion because it is an intervention aimed at reducing chest wall stiffness.

PLB impacts breathing patterns by extending expiration, reducing functional recidual capacity (FRC) and increasing ventilation efficiency. In COPD patients with low peak expiratory flow, PLB can reduce dynamic hyperinflation and improve exercise tolerance, breathing patterns and arterial oxygenation in submaximal intensity exercise ${ }^{6}$. PLB is a strategy that is carried out by holding the lips together during controlled exhalation. The PLB is thought to keep the airways open by creating back pressure in the air ducts. Studies show that PLB reduces the respiratory rate and work of breathing (oxygen consumption), increases tidal volume, and increases exercise tolerance ${ }^{12}$.

Treatment in all intervention groups was given with the same intensity and time of exercise. Judging from the various impairments that occur in COPD patients, it is necessary to combine interventions to reduce these impairments and various measures to evaluate the results of these interventions. Many previous studies have used FEV1 with units of liters (L), SpO2, FEV1 / FVC, or the expansion of a thoracic cage for evaluation, where researchers did not measure these aspects. Chest mobilization intervention gave a significant result on the development of the thoracic cage, decreased shortness of breath and hyperinflation and increased 6 MWT but not FEV1 (\%). He also stated that there was no relationship between thoracic cage development and an increase in FEV1 $(\%)^{13}$.

Relaxation exercises, flexibility or stretching exercises, and breathing techniques (e.g, PLB and diaphragmatic breathing) often combined with exercise sessions can prove useful in a pulmonary rehabilitation program. This exercise is given for short periods (5-10 minutes) and is recommended to maintain muscle length and to prevent pain relief ${ }^{14}$. Judging from the frequency and duration of the study, which is 3 times a week for 6 weeks, this is enough time to see any changes in giving chest mobilization and PLB interventions. Both chest mobilization and PLB have an effect on decreasing lung hyperinflation, thereby increasing FEV1 and decreasing shortness of breath.

Research conducted, showed an increase in chest cage mobility and an increase in the FEV1 / FVC ratio after rib cage mobilization for 3 weeks, 5 days a week ${ }^{5}$. Another study was conducted by Parmar and Bhise whose results showed that chest mobilization had a significant direct result in increasing lung development in COPD ${ }^{4}$. Research conducted by Bakry et al clarified the effect of pulmonary rehabilitation programs in COPD patients. The short-term PR program (6-8 weeks) especially the aerobic training program has the capacity to reduce tightness, increase activity tolerance and exercise intolerance, improve physiological parameters (FVC and FEV1) and improve several components of the BODE index. Most of the previous studies indicated that the pulmonary rehabilitation program duration was longer than 6 weeks. The benefits of a pulmonary rehabilitation program tend to diminish for months after discharge, usually after 12 months. However, a program that lasts for at least 6 months is better at maintaining results, even in the absence of a structured maintenance program but by means of changes in physical activity and lifestyle changes which are important challenges for those who have undergone a comprehensive pulmonary rehabilitation program ${ }^{14,15}$.

\section{CONCLUSION}

Based on the results, it can be concluded that the addition of chest mobilization or PLB intervention can increase FEV1 and reduce shortness of breath in COPD patients. However, the addition of this intervention to conventional therapy was as good as in increasing FEV1 and reducing shortness of breath in COPD patients at the Lung Hospital, dr. Ario Wirawan Salatiga. 


\section{CONFLICT OF INTEREST}

The research subjects had different threshold for fatigue, cognitive levels and moods. This causes the researcher to explain well about the spirometry measurement instructions and the modified Borg scale questionnaire according to the language understood by the patient. In addition, nutrition, physical activity and sleep quality could not be controlled by researchers. Future research may use other evaluations such as increased thoracic cage or oxygen saturation and follow up to determine long-term effects.

\section{ACKNOWLEDGEMENT}

My gratitude goes to the physiotherapy staff at the Lung Hospital dr. Ario Wirawan Salatiga, my lecture in Udayana University and all research subjects who have taken the time to help this research. We also gratitude to our parents and family who always supported us in completing this thesis.

\section{REFERENCES}

1. Nyberg, A., Carvalho, J., Bui, K. L., Saey, D. \& Maltais, F. Adaptations in limb muscle function following pulmonary rehabilitation in patients with COPD - A review. Rev. Port. Pneumol. (English Ed. 22, 342-350 (2016).

2. Depkes. Butelin Jendela Data Data dan Informasi Kesehatan. Penyakit Tidak Menular 2012. http://www.depkes.go.id/download.php?file=download/pusdatin/buletin/buletin-ptm.pdf (2019).

3. Mulay, S. U., Devi, T. P. \& Jagtap, V. K. Effectiveness of Shoulder and Thoracic Mobility Exercises on Chest Expansion and Dyspnoea in Moderate Chronic Obstructive Pulmonary Disease Patients. Int. J. Physiother. Res. 5, 1960-1965 (2017).

4. Parmar, D. \& Bhise, A. The Immediate effect of Chest Mobilization Technique on Oxygen Saturation in Patients of COPD with Restrictive Impairment. Indian J. Physiother. Occup. Ther. - An Int. J. 4, 2413-2416 (2015).

5. Rehman, S. U., Rehman, M., Siddique, F. A., Khan, A. \& Sibtain, F. The efficacy of rib cage mobilization on lung function in COPD patients. Rawal Med. J. 38, 36-39 (2013).

6. Cabral, L. F., D’Elia, D. C., Marins, D. S., Zin, A. \& Guimarães, S. Pursed lip breathing improves exercise tolerance in COPD: A randomized crossover study. Eur. J. Phys. Rehabil. Med. 51, 79-88 (2014).

7. Visser, F. J., Ramlal, S., Dekhuijzen, P. \& Heijdra, Y. Pursed Lip Breathing Improves Inspiratory Capacity in COPD. 81, 372-378 (2010).

8. Hasan, H. \& Maranatha, R. A. Perubahan Fungsi Paru Pada Usia Tua. J. Respirasi 3, $52-57$ (2017).

9. Leelarungrayub, D. Chest Mobilization Techniques for Improving Ventilation and Gas Exchange in Chronic Lung Disease. Chronic Obstructive Pulmonary Disease. (Chiang Mai University., 2012).

10. Yelvar, G., Cirak, Y., Demir, Y., Dalkilinc, M. \& Bozkurt, B. Immediate effect of manual therapy on respiratory functions and inspiratory muscle strength in patients with COPD. Int. J. COPD 11, 1353-1357 (2016).

11. Lim, S. J. et al. Altered Thoracic Cage Dimensions in Patients with Chronic Obstructive Pulmonary Disease. Tuberc. Respir. Dis. (Seoul). 81, 123-131 (2018).

12. Kisner, C. \& Colby, L. Therapeutic Exercise: Foundation and techniques. (Philadelphia: F. A Davis Company, 2007).

13. Balogh, Z., Lengyel, L. \& Varga, J. Role of Chest Expansion in Pulmonary Rehabilitation. in Annual Congress 2013 (2013).

14. Corhay, J. L., Dang, D. N., Cauwenberge, H. W. \& Louis, R. Pulmonary rehabilitation and COPD: providing patients a good environment for optimizing therapy. 9, 7-39 (2014).

15. Bakry, E., Elhadidi, A. A., Masood, H. H. \& Mohammed, A. R. Pulmonary rehabilitation in chronic obstructive pulmonary disease The Egyptian Society of Chest Diseases and Tuberculosis. Egypt. J. Chest Dis. Tuberc. 62, 359-369 (2015). 